\title{
THEORETICAL STUDY OF EARTH PRESSURE AT - REST FOR SANDY SOILS
}

\author{
El Sharif M. Abdel Aziz', Yehia K. Taha ${ }^{2}$, and Samy N. Eweada ${ }^{3}$ \\ ${ }^{l}$ Civil Eng., Dept., Faculty of Engineering Assiut University, Assiut, Egypt. \\ ${ }^{2}$ Civil Eng., Dept., Faculty of Engineering Assiut University, Assiut, Egypt. \\ ${ }^{3}$ Eng., General Authority for Educational Buildings
}

(Received December 5, 2010 Accepted Journey 13, 2011)

\begin{abstract}
The solution of many foundations - engineering problems requires knowledge of the lateral pressure which may be exerted by the earth or surcharge loads.

The lateral earth pressure is a significant design parameter in many of the foundation engineering problems subjected to lateral pressures commonly used as parts of many civil engineering projects. Some examples of these structures are, retaining walls, sheet-pile walls, both braced and unbraced excavations, trench excavations, grain pressures on silo walls, cofferdams, caissons, embedded shells and other types of underground structures requiring an estimation of the lateral pressure for design or stability analysis.

The different formulae such as Jaky, Hendron, Brooker and Ireland, Vierzbiczky, Saglamer , Wenkow , Robert Szepeshazi , Matsuoka et al, Bolton, and others were used to determine the factor $\mathrm{K}_{\mathrm{o}}$.

The main aim of this research is to estimate the coefficient of earth pressure at rest equation depending on the theoretical relationship between the active, passive earth pressures and the lateral strain of soil.

The important result from this research is:

$K_{o}=\left(1-\sin ^{2} \phi\right) /\left(1+\sin ^{2} \phi\right)$

The research included other important results.
\end{abstract}

KEYWORDS: Earth pressure, $\mathrm{K}_{\mathrm{o}}$, coefficient of earth pressure at rest.

\section{INTRODUCTION}

The internationally most recognized achievement of soil mechanics research in Hungary has been the formula for the earth pressure at- rest. Jaky[3]

$\mathbf{K}_{\mathrm{o}}=1-\sin \phi$

The earth pressure at - rest represented by its coefficient $\mathrm{K}_{\mathrm{o}}$, has first been interpreted by Donath [1], while Terzaghi [2] was the first to publish measurement data for $\mathrm{K}_{\mathrm{o}}$. The first theoretical approach to the problem is due to Jaky [3], and subsequent modifications of his theory formulated at that time resulted in Eq. (1).

In up-to-date computerized F.E.M geotechnical design procedures, the $\mathrm{K}_{\mathrm{o}}$ factor is usually required as an input, and computations show this value to have a significant effect on the safety factor of slope stability (Lo and Lee [4]), or slurry trench wall behavior (Fourie and Potts [5]). 


\section{NOTATION}

\begin{tabular}{|c|c|c|c|}
\hline $\mathrm{E}$ & modulus of elasticity of soil & $v$ & poisson's ratio. \\
\hline $\mathrm{E}_{\mathrm{h}}$ & $\begin{array}{l}\text { horizontal modulus of elasticity of } \\
\text { the soil. }\end{array}$ & $\sigma_{1}$ & vertical pressure. \\
\hline $\mathrm{E}_{\mathrm{v}}$ & $\begin{array}{l}\text { vertical modulus of elasticity of } \\
\text { the soil. }\end{array}$ & $\sigma_{3}$ & lateral pressure. \\
\hline $\mathrm{k}_{\mathrm{a}}$ & coefficient of active earth pressure. & $\sigma_{\mathrm{h}}$ & horizontal earth pressure. \\
\hline $\mathrm{K}_{\mathrm{o}}$ & $\begin{array}{l}\text { coefficient of lateral earth pressure } \\
\text { at - rest }\end{array}$ & $\sigma_{\mathrm{v}}$ & vertical earth pressure. \\
\hline $\mathrm{K}_{\mathrm{p}}$ & $\begin{array}{l}\text { coefficient of passive earth } \\
\text { pressure. }\end{array}$ & $\phi$ & $\begin{array}{l}\text { the angle of internal friction of } \\
\text { soil. }\end{array}$ \\
\hline $\mathrm{P}_{\mathrm{a}}$ & active earth pressure. & $\phi_{\mathrm{e}}$ & $\begin{array}{l}\text { the angle of shear strength } \\
\text { mobilized at - rest. }\end{array}$ \\
\hline $\mathrm{P}_{\mathrm{o}}$ & lateral earth pressure at - rest. & $\phi_{\mathrm{mob}}$ & $\begin{array}{l}\text { mobilized angle of internal } \\
\text { friction of soil. }\end{array}$ \\
\hline$P_{p}$ & passive earth pressure. & $\varepsilon_{3}$ & the lateral strain. \\
\hline
\end{tabular}

The coefficient of lateral earth pressure under condition of no lateral deformation, $K_{o}$ has been of interest to soil engineers for over 100 years. $K_{o}$ is an essential parameter in the design or analysis of many conventional problems. For example, $\mathrm{K}_{\mathrm{o}}$ is commonly used to compute lateral thrusts against earth - retaining structures where the lateral movement is too small to mobilize the active state of stress. The coefficient $\mathrm{K}_{\mathrm{o}}$ has also been used in the computation of lateral swelling pressures against friction piles in expansive soils.

Donath [1] was the first to introduce the term "coefficient of earth pressure atrest" $K_{0}$, referring to the condition where no yielding occurs. He defined this coefficient as the ratio of the horizontal $\left(\sigma_{h}\right)$ to the vertical $\left(\sigma_{v}\right)$ earth pressure resulting in soil due to the application of vertical load with constrained lateral deformation $\left(\mathrm{K}_{\mathrm{o}}=\sigma_{\mathrm{h}} / \sigma_{\mathrm{v}}\right)$.

Terzaghi [2] reported results of a comprehensive study on the evaluation of $K_{0}$ for a variety of soils, and studied the effect of compaction on the value of $\mathrm{K}_{\mathrm{o}}$.He found that the value of $K_{o}$ for coarse sand was 0.42 , and when the sand was compacted in layers with a hand compactor, $\mathrm{K}_{\mathrm{o}}$ increased to a value between 0.6 and 0.7 .

Kjellman [6] developed a complicated triaxial apparatus, in which the three principal stresses could be reported and values of $\mathrm{K}_{\mathrm{o}}$ vary between 0.5 and 1.5 for the tested sand. He concluded that $\mathrm{K}_{\mathrm{o}}$ was a function of the stress history of the sand.

Jaky [7] conducted a theoretical study on $\mathrm{K}_{\mathrm{o}}$ and introduced the following theoretical expression to calculate the value of $\mathrm{K}_{\mathrm{o}}$ as:

$\mathrm{K}_{0}=\left[1+\frac{2}{3} \sin \phi\right]\left[\frac{1-\sin \phi}{1+\sin \phi}\right]$

Where $\phi=$ the angle of shearing resistance of the soil.

Jaky [8] presented a simplified version of the expression given by:

$\mathbf{K}_{0}=1-\sin \phi$ 
These expressions were the first attempts to relate the coefficient of earth pressure at rest with the angle of shearing resistance of the soil. The expression is still widely used due to its practical significance and attractive simplicity.

Bishop [9] stated that $K_{o}$ is the ratio of the lateral to the vertical effective stresses in a soil consolidated under the condition of no lateral deformation.

Hendron [10] proposed the following expression relating $\mathrm{K}_{\mathrm{o}}$ and $\phi$

$$
K_{0}=\frac{1}{2}\left[\frac{1+\frac{\sqrt{5}}{8}-3 \frac{\sqrt{5}}{8}(\sin \phi)}{1-\frac{\sqrt{5}}{8}+3 \frac{\sqrt{5}}{8}(\sin \phi)}\right]
$$

$\mathrm{He}$ concluded that the values of $\mathrm{K}_{\mathrm{o}}$ for round sand are lower than for an angular one at identical values of the angle of shearing resistance, and suggested that the angle of shearing resistance is not a completely unique parameter for the value of $\mathrm{K}_{\mathrm{o}}$.

Saglamer [11] proposed the following equation to calculate the value of $\mathrm{K}_{\mathrm{o}}$ for sands as:

$$
\mathrm{K}_{\mathrm{o}}=0.97[1-0.97(\sin \phi)]
$$

Wenkow [12] tested the cohesive and non - cohesive soils and presented for case of sand clayey sands the following theoretical relation:

$\mathrm{K}_{\mathrm{o}}=\sqrt{\mathrm{K}_{\mathrm{a}}}$

Where:

$\mathrm{K}_{\mathrm{a}}=$ the coefficient of active earth pressure.

Tschebotarioff [13] estimated the coefficient of earth pressure at- rest by theory of elasticity. The general equation for the lateral unit strain $\epsilon_{3}$ within a large elastic body is as follows:

$\epsilon_{3}=\frac{1}{E}\left[\sigma_{3}-v\left(\sigma_{1}+\sigma_{3}\right)\right]$

Where $\epsilon_{3}=0$ then this equation leads to

$\mathrm{K}_{0}=\frac{\vec{\sigma}_{\mathrm{g}}}{\vec{\varepsilon}_{\mathrm{a}}}=\frac{v}{i-v}$

Where $v$ the Poisson 's ratio of soil.

Robert Szepeshazi [14] determined $K_{0}$, omitting details, as:

$$
K_{o}=(1-\sin \phi)\left[1-\frac{\sin \phi}{(1+\sin \phi)(\sin \phi+3+\sqrt{4.5+4 \sin \phi}}\right]
$$

At $40^{\circ}>\phi>20^{\circ}$ this intricated formula may be properly approximated (with a maximum error $1.2 \%$ ) as:

$K_{0}=0.95(1-\sin \phi)$.

Vierzbiczky [14] applied the Rankine factor, assuming a mobilization of two thirds of the internal friction angle and suggested that the coefficient of earth pressure at-rest to be:

$$
K_{0}=\tan ^{2}\left(45-\frac{\phi}{3}\right)
$$

Brooker and Ireland [15] suggested the coefficient of earth pressure at-rest to be:

$\mathrm{K}_{\mathrm{o}}=0.95-\sin \phi$ 
Matsuoka and Sakakibara [16] suggested the coefficient of earth pressure atrest as:

$\mathrm{K}_{0}=\frac{1}{(1+2 \sin \phi)}$

Where $\phi$ is the angle of internal friction of soils.

Bolton [17] proposed an equation based on the study of sands in the form:

$\mathrm{K}_{\mathrm{o}}=\frac{1-\sin \phi_{\mathrm{mob}}}{1+\sin \phi_{\mathrm{mob}}}$

Where $\phi_{\text {mol }}=\phi-11.5^{\circ}$

Rowe [18] derived the following expression:

$$
\mathrm{K}_{\mathrm{o}}=\tan ^{2}\left(45-\frac{\phi_{8}}{2}\right) \text {. }
$$

In which $\phi_{a}=$ the angle of shear strength mobilized at - rest

$\phi_{e}=1.15(\phi-9)$

Andrawes and El- Sohby [19] concluded that the $\mathrm{K}_{0}$ value depends not only on the angle of internal friction $\phi$ but also on the surface roughness and angularity, they concluded that $K_{\circ}$ decreases with increasing the angularity and the grain size.

Andrawes and El-Sohby [20] concluded that the increase in the value of porosity, crushing, and modulus of elasticity of the mineral particles causes the value of $K_{0}$ to increase. Also, they concluded that $K_{0}$ is not solely a function of the angle of shearing resistance $(\phi)$, as suggested by Jaky $(1944,1948)$.

Hanna and Ghaly [21] concluded that the coefficient of earth pressure at rest $\mathrm{K}_{0}$ is affected by the effective angle of shearing resistance, shape and interlocking of soil particles, amount of fines in the soil, porosity, crushing, Modulus of elasticity of the mineral particles, compacting method, stress history, and applied stress level.

Moroto and Muramatsu [22] derived a theoretical equation to determine $K_{0}$ based on the anisotropy of an over consolidated clay soil. Their equation is based on the ratio of the horizontal modulus of elasticity $\left(E_{h}\right)$ of the soil to it's vertically elasticity $\left(E_{w}\right)$ as:

$\mathbf{K}_{0}=\sqrt{\frac{I_{\mathrm{h}}}{I_{V}}}$.
$\mathbf{K}_{0}=\frac{1-\sin ^{2} \phi}{1+\sin ^{2} \phi}$

\section{ANALYSIS OF THE PRESENT EQUATION}

Referring to Fig. (1), it is noted in the relationship between lateral strain and lateral pressure coefficient that the active earth pressure appeared when the construction moves away from backfill in this case lateral expansion of the soil occurs. The passive earth pressure appeared when the construction moves towards the backfill, this is analogous to pushing a wall laterally against the soil 


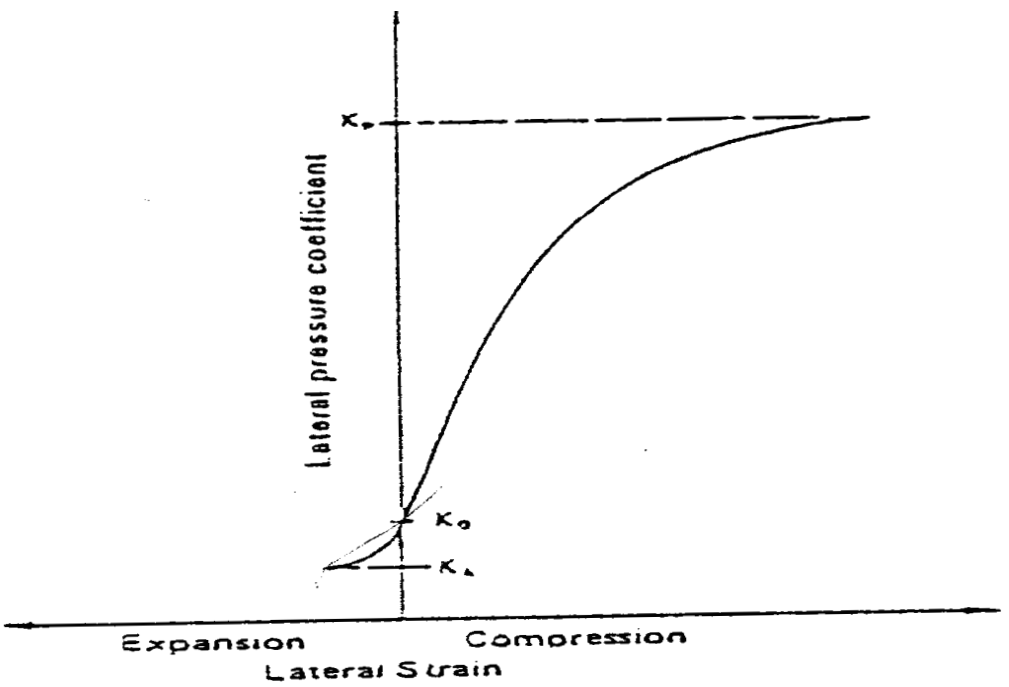

Fig. (1) Relation between lateral strain and lateral pressure coefficient [23]

If the lateral strain in the soil is zero or very small in the structure or if earth pressure acting on motionless retaining wall, the corresponding lateral earth pressure is called the pressure at-rest

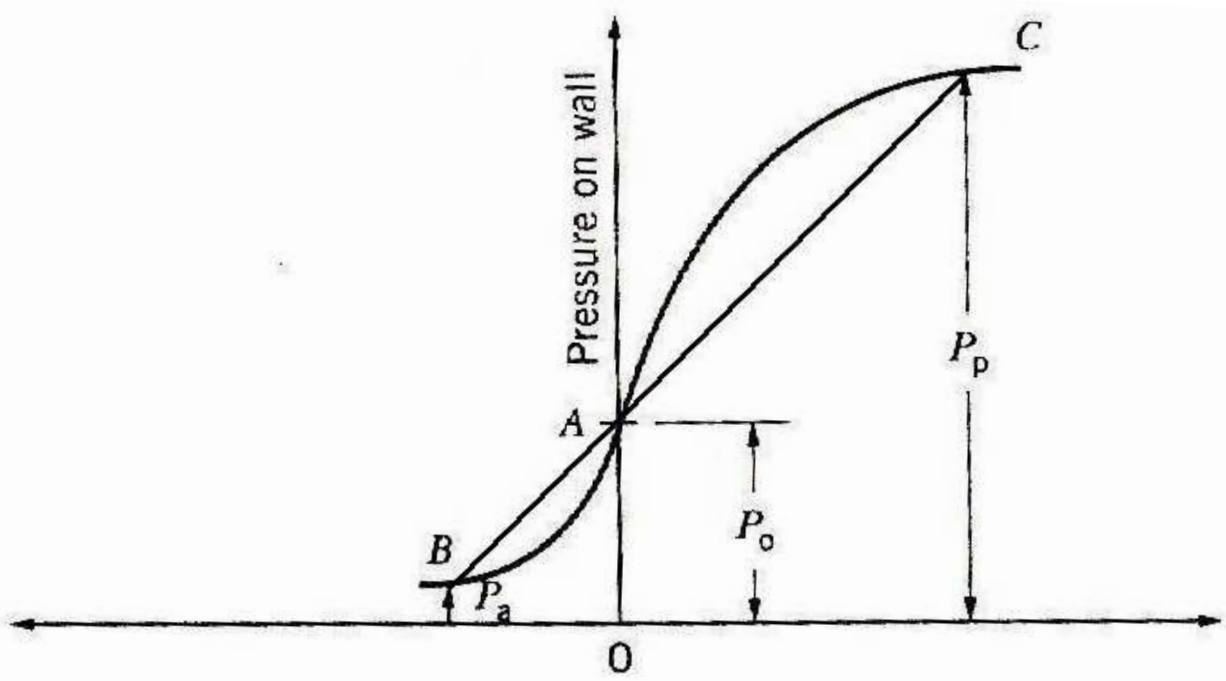

Away from backfill

Toward backfill

Direction of wall movement

Fig. (2) Relationship between

lateral strain and

lateral pressure coefficient. 
By considering the soil as elastic, isotropic, homogenous, and considering the idealized relationship between lateral strain and lateral pressure (line $B C$ ).

The geometric shape in Fig. (2) Leads to

$$
\begin{aligned}
& \frac{P_{\mathrm{o}}-\mathrm{P}_{\mathrm{a}}}{\mathrm{P}_{\mathrm{p}}-\mathrm{P}_{\mathrm{a}}}=\frac{\epsilon_{\mathrm{a}}}{\epsilon_{\mathrm{a}}+\epsilon_{\mathrm{p}}} \\
& \frac{\mathrm{P}_{\mathrm{o}}-\mathrm{P}_{\mathrm{a}}}{\mathrm{P}_{\mathrm{p}}-\mathrm{P}_{\mathrm{a}}}=\frac{\frac{\mathrm{P}_{\mathrm{a}}}{\mathrm{E}}}{\frac{\mathrm{P}_{\mathrm{a}}}{\mathrm{P}}+\frac{\mathrm{P}_{\mathrm{p}}}{\mathrm{E}}} \\
& \frac{\mathrm{P}_{\mathrm{o}}-\mathrm{P}_{\mathrm{a}}}{\mathrm{P}_{\mathrm{p}}-\mathrm{P}_{\mathrm{a}}}=\frac{\mathrm{P}_{\mathrm{a}}}{\mathrm{P}_{\mathrm{a}}+\mathrm{P}_{\mathrm{p}}} \\
& \left(\mathrm{P}_{\mathrm{o}}-\mathrm{P}_{\mathrm{a}}\right)\left(\mathrm{P}_{\mathrm{a}}+\mathrm{P}_{\mathrm{p}}\right)=\mathrm{P}_{\mathrm{a}}\left(\mathrm{P}_{\mathrm{p}}-\mathrm{P}_{\mathrm{a}}\right) . \\
& \mathrm{K}_{\mathrm{o}} \mathrm{K}_{\mathrm{a}}+\mathrm{K}_{\mathrm{o}} \mathrm{K}_{\mathrm{p}}-\mathrm{K}_{\mathrm{a}}^{2}-\mathrm{K}_{\mathrm{a}} \mathrm{K}_{\mathrm{p}}=\mathrm{K}_{\mathrm{a}} \mathrm{K}_{\mathrm{p}}-\mathrm{K}_{\mathrm{a}}^{2} \\
& \mathrm{~K}_{\mathrm{o}} \mathrm{K}_{\mathrm{a}}+\mathrm{K}_{\mathrm{o}} \mathrm{K}_{\mathrm{p}}=2 \mathrm{~K}_{\mathrm{a}} \mathrm{K}_{\mathrm{p}} \\
& \mathrm{K}_{\mathrm{o}}=\frac{2 \mathrm{~K}_{\mathrm{a}} \mathrm{K}_{\mathrm{p}}}{\mathrm{K}_{\mathrm{a}}+\mathrm{K}_{\mathrm{p}}} \\
& \mathrm{K}_{\mathrm{a}}=\frac{1}{\mathrm{~K}_{\mathrm{p}}}=\frac{1-\sin \phi}{1+\sin \phi}
\end{aligned}
$$

Substituting in Eq.(27) into Eq.(26), we obtain

$$
K_{\circ}=\frac{1-\sin ^{2} \phi}{1+\sin ^{2} \phi}
$$

\section{RESULTS AND DISCUSSION}

Jaky's equation is often referred to as the base of comparison in appreciating most of new theoretical or measurement results [14]. It's better to compare all different types of equation which used to determine the coefficient of earth pressure at rest including of course the current equation to Jaky's equation. The relationship between the angle of internal friction, $\phi$ and the coefficient of earth pressure at rest, $K_{0}$ for sandy soils are plotted in Fig. (3). 


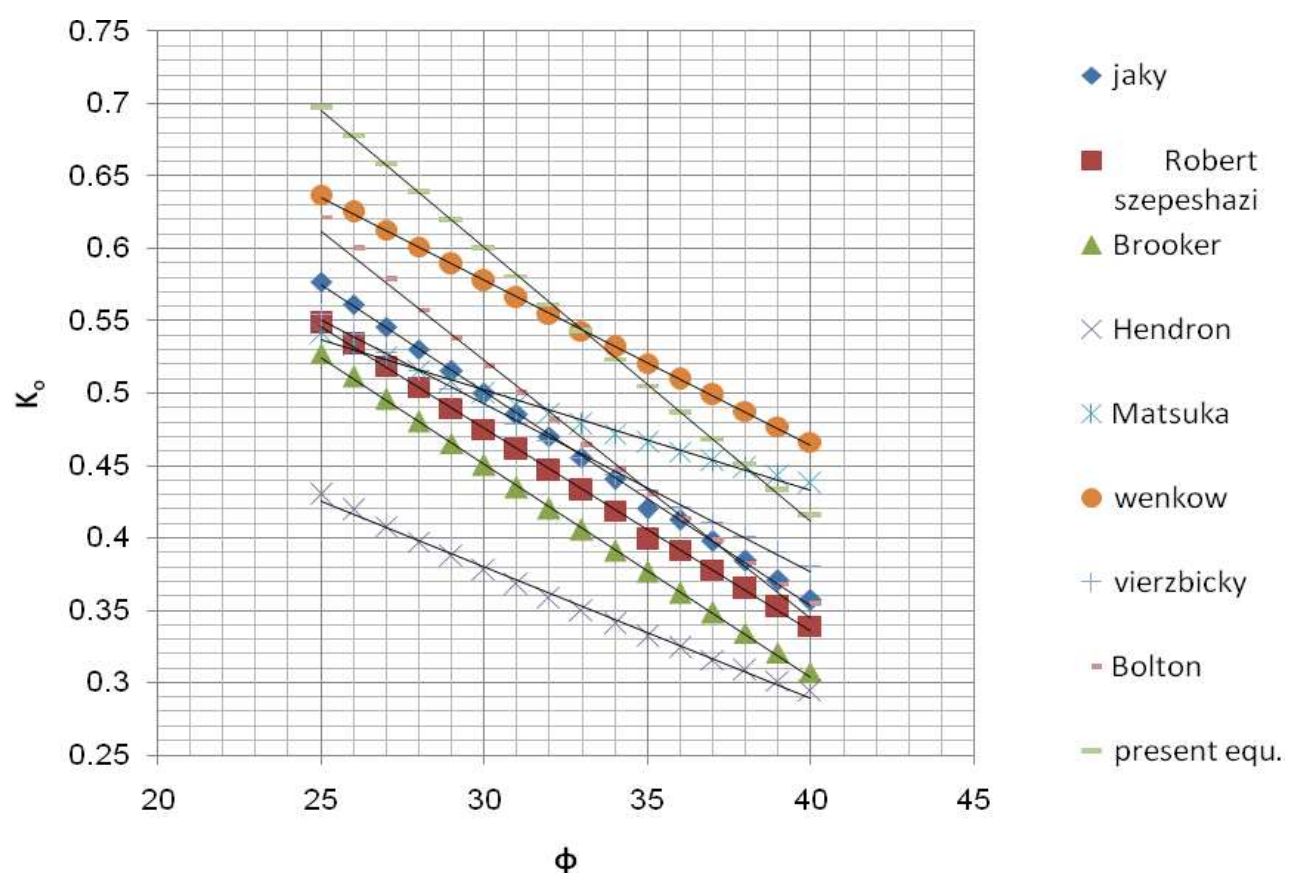

Fig. (3) Relations between $\varphi$ and different aspects of the formula for the coefficient of earth pressure at rest for cohesionless soils.

The relationships can be represented by straight lines as follows:

$$
\begin{aligned}
& \mathrm{K}_{\mathrm{o}}=0.96429-0.01548 \phi \quad \ldots \ldots \ldots \ldots \ldots \ldots \ldots \text { for Jaky } \\
& \mathrm{K}_{\mathrm{o}}=1.0544-0.017946 \phi \quad \ldots \ldots \ldots \ldots \ldots \ldots \ldots . \quad \text { for Bolton } \\
& \mathrm{K}_{\mathrm{o}}=0.895-0.014 \phi \quad \ldots \ldots \ldots \ldots \ldots \ldots \ldots \ldots \ldots \ldots \ldots \text { for Robert Szepeshazi } \\
& \mathrm{K}_{\mathrm{o}}=0.8905-0.0147 \phi \quad \ldots \ldots \ldots \ldots \ldots \ldots \ldots . \quad \text { for Brooker } \\
& K_{\circ}=0.91887-0.011396 \phi \ldots \ldots \ldots \ldots \ldots \ldots . \quad \text { for Wenkow } \\
& \mathrm{K}_{0}=0.64925-0.009 \phi \ldots \ldots \ldots \ldots \ldots \ldots \ldots \ldots . \ldots \ldots \ldots \text { for Hendron } \\
& K_{0}=0.8379-0.0116 \phi \ldots \ldots \ldots \ldots \ldots \ldots \ldots \ldots . \quad \text { for Vierzbicky } \\
& \mathrm{K}_{\mathrm{o}}=0.70925-0.00698 \phi \ldots \ldots \ldots \ldots \ldots \ldots \ldots \ldots \text { for Matsuka } \\
& \mathrm{K}_{\mathrm{o}}=1.16414-0.01884 \phi \ldots \ldots \ldots \ldots \ldots \ldots \ldots . \quad \text { for Present equ. }
\end{aligned}
$$

Where $\phi$ is in degrees.

From Fig. (3) it can be noticed that for the present equation, the coefficient of earth pressure at rest, $K_{0}$ decreases with the increase of the angle of internal friction, $\phi$ 


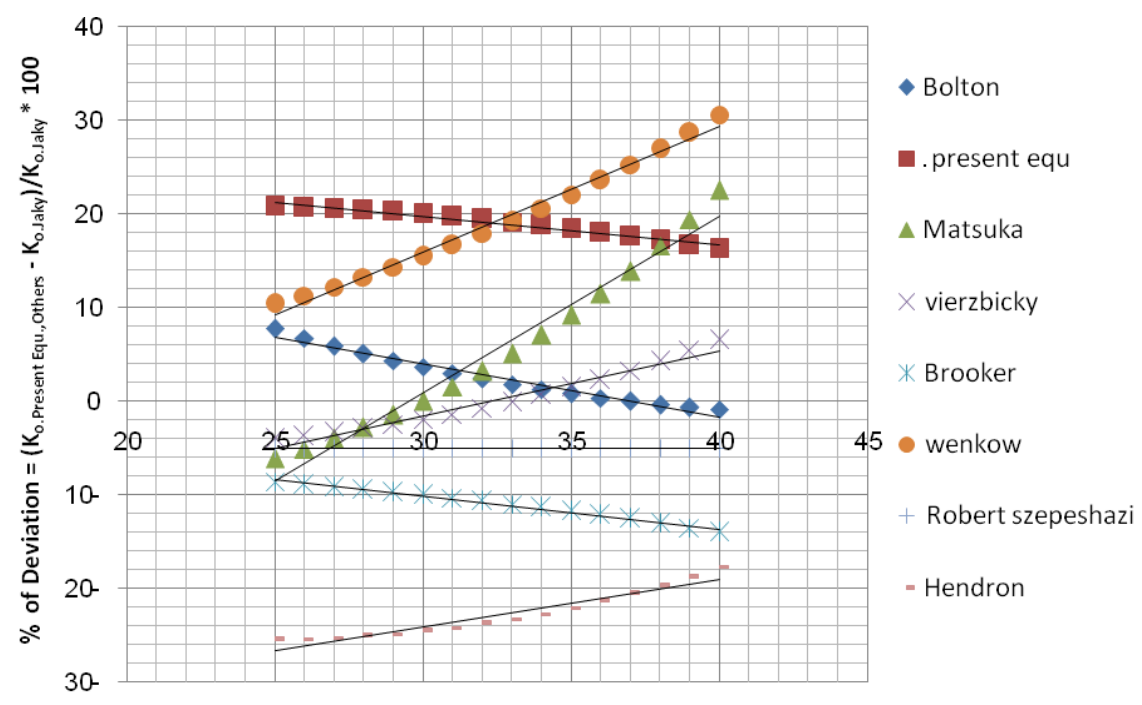

Fig. (4) Relations between the angle of internal friction, $\phi$ and \% Deviation between Jaky and Present Equ. ,Others

Figure (4) Shows the Relations between the angle of internal friction $\phi$, and $\%$ of Deviation between Jaky, present equation, and others . It can be noticed that, for the present equ.and Jakys'equ. The deviation is about $20 \%$ at $\phi=25: 30$, about $19 \%$ at $\phi=31: 33$, about $18 \%$ at $\phi=34: 36$ and about $16.5 \%$ at $\phi=37: 40^{\circ}$

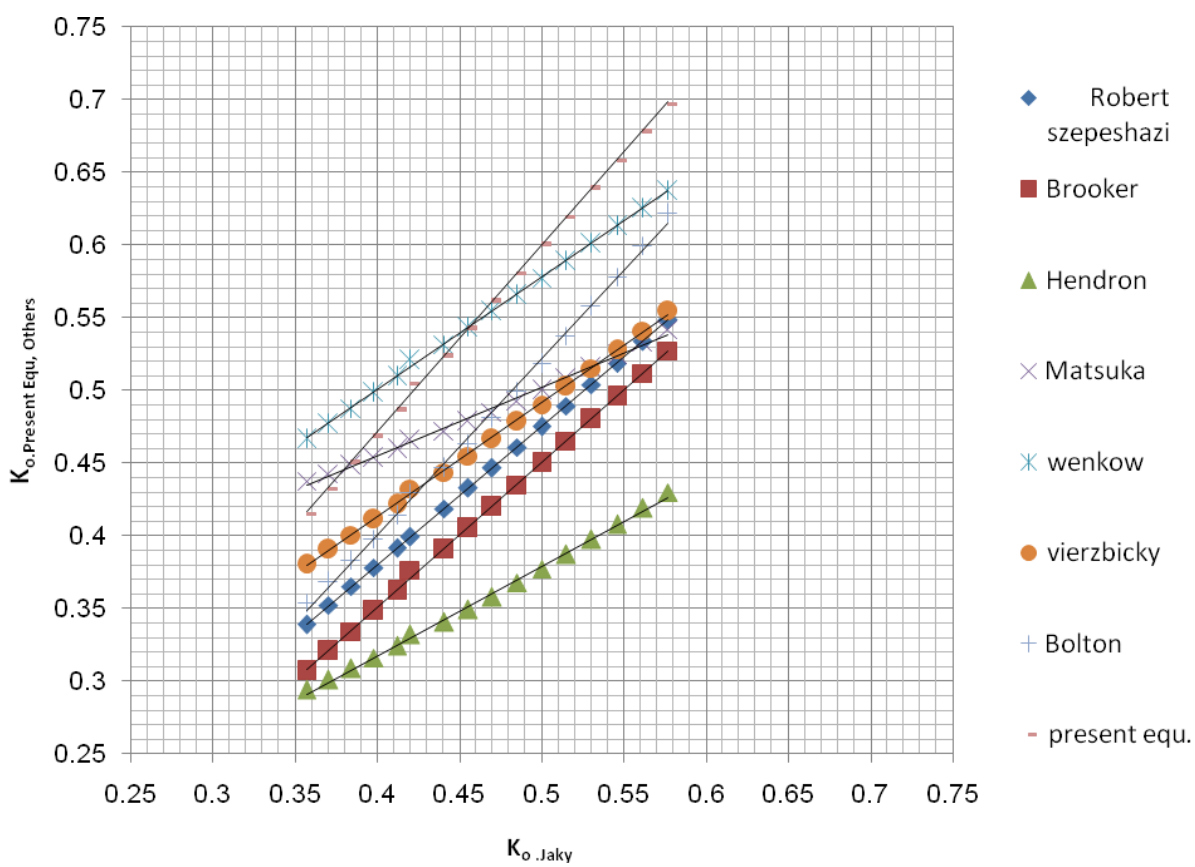

Fig. (5) Relations between $K_{o}$. Jaky and results of $K_{0}$.Present equ., Others 
The relationships between $\mathrm{K}_{\mathrm{o}}$ from Jaky and $\mathrm{K}_{\mathrm{o}}$ from present equ. and others for sand soil are plotted in Fig. (5) $\mathrm{K}_{\mathrm{o}}$ from present equ. and others relatively with $\mathrm{K}_{\mathrm{o}}$ from Jaky.

The relationships can be represented as straight line as follows:

$$
\begin{aligned}
& \mathrm{K}_{\text {oRobert }}=0.95 \mathrm{~K}_{\text {oJaky }} \\
& \mathrm{K}_{\text {oBrooker }}=0.98707 \mathrm{~K}_{\text {oJaky }}-0.04353 \\
& \mathrm{~K}_{\text {oHendron }}=0.63736 \mathrm{~K}_{\text {oJaky }}+0.05881 \\
& \mathrm{~K}_{\text {o Matsuka }}=0.46975 \mathrm{~K}_{\text {oJaky }}+0.266 \\
& \mathrm{~K}_{\text {oWenkow }}=0.7756 \mathrm{~K}_{\text {oJaky }}+0.18984 \\
& \mathrm{~K}_{\text {o vierzbicky }}=0.78852 \mathrm{~K}_{\text {oJaky }}+0.09639 \\
& \mathrm{~K}_{\text {oBolton }}=1.2165 \mathrm{~K}_{\text {oJaky }}-0.08905 \\
& \mathrm{~K}_{\text {opresent }}=1.2795 \mathrm{~K}_{\text {oJaky }}-0.04044
\end{aligned}
$$

From Fig. (5) at $\phi=25: 40^{\circ}$ it can be noticed that $\mathrm{K}_{\mathrm{o}}$ present increases with increase $\mathrm{K}_{\text {o.Jaky }}$

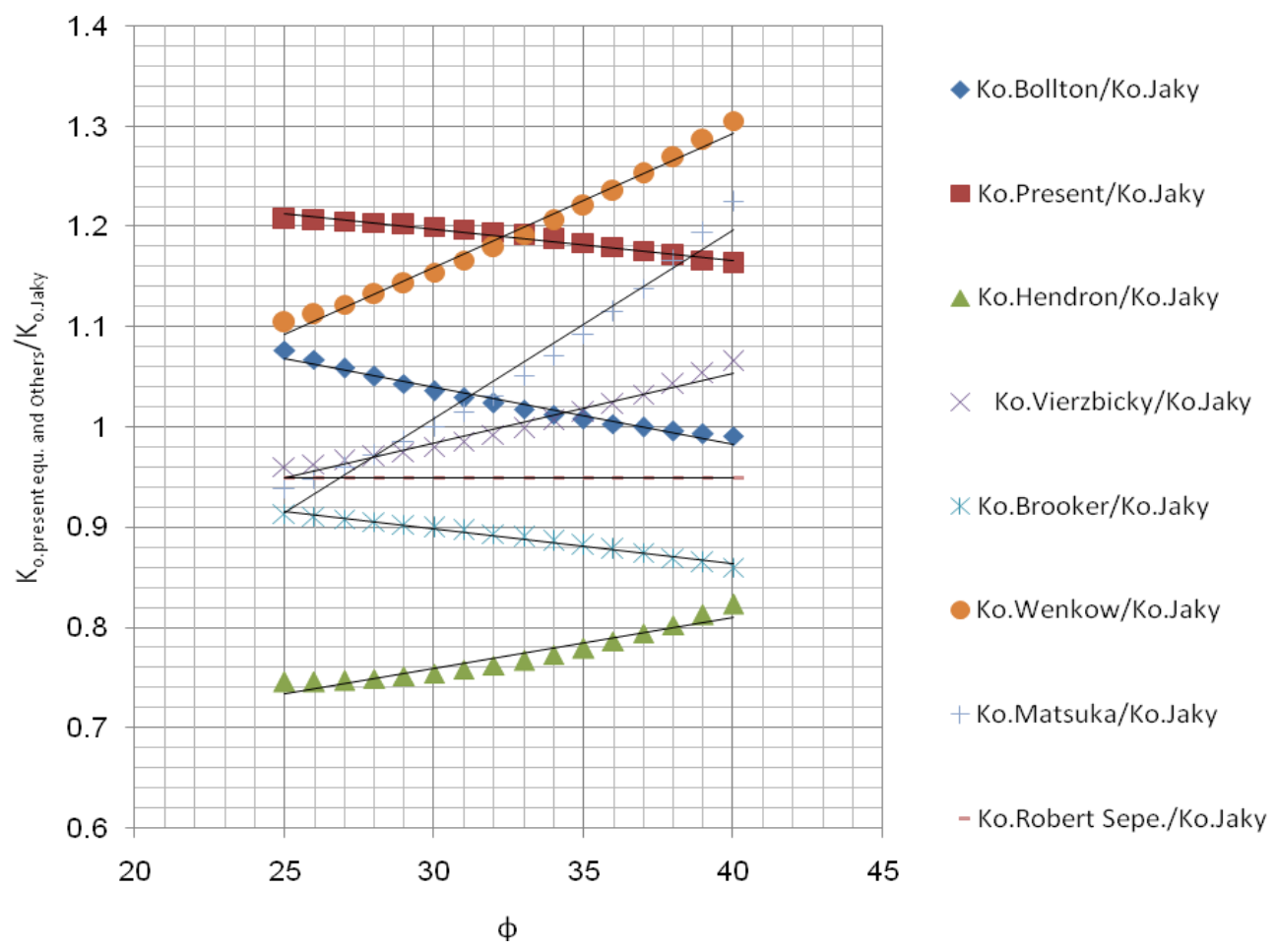

Fig. (6) Relations between $\mathrm{K}_{\text {o.present equ.and Others }} / \mathrm{K}_{\text {o.Jaky }}$ and the angle of internal friction, $\phi$

The relationship between the angle of internal friction, $\phi$ and the coefficient of earth pressure at rest, $\mathrm{K}_{\mathrm{o}} / \mathrm{k}_{\mathrm{o} \text {.Jaky }}$ for sand soil are plotted in Fig. (6) 
The relationships can be represented by straight lines as follows:

$\mathrm{K}_{\mathrm{oRobert}} / \mathrm{K}_{\mathrm{o} \text { Jaky }}=0.95$.

$\mathrm{K}_{\mathrm{oBolton}} / \mathrm{K}_{\mathrm{o} \text { Jaky }}=1.1998-0.0055 \phi$

$\mathrm{K}_{\text {oPresent }} / \mathrm{K}_{\mathrm{o} \mathrm{Jaky}}=1.3011-0.0033 \phi$

$\mathrm{K}_{\mathrm{o} \text { Hendron }} / \mathrm{K}_{\mathrm{o} \text { Jaky }}=0.606+0.005 \phi$

$\mathrm{K}_{\mathrm{o} \text { Vierzbicky }} / \mathrm{K}_{\mathrm{o} \text { Jaky }}=0.0072 \phi+0.76305$

$\mathrm{K}_{\mathrm{o} \text { Brooker }} / \mathrm{K}_{\mathrm{o} \text { Jaky }}=1.00719-0.00356 \phi$

$\mathrm{K}_{\mathrm{oWenkow}} / \mathrm{K}_{\mathrm{o} \text { Jaky }}=0.013 \phi+0.758$

$\mathrm{K}_{\text {oMatsuka }} / \mathrm{K}_{\mathrm{o} \mathrm{Jaky}}=0.01913 \phi+0.43042$

Where $\phi$ in degree

From Fig.(6) for $\phi=25: 40^{\circ}$ the relation between the $\mathrm{K}_{\mathrm{o} \text { present }} / \mathrm{K}_{\mathrm{o} \text { Jaky }}$ and $\phi$ presented as nearly horizontal straight line up to $33^{\circ}$ and equals 1.2 and deceases to reach 1.16 at $40^{\circ}$.

\section{CONCLUSIONS}

Due to the great importance of the coefficient of earth pressure at rest $K_{0}$ and through the wide investigation performed on the available formulae, it was able to introduce a new equation to compute $K_{0}$ for sandy soils.

Such equation depends on: the active, passive earth pressure and the lateral strain of soil. This formula is found to be in good agreement with the most famous equations usually used to determine such coefficient.

The findings are summarized as follows:-

1. The present equation is:

$$
K_{o}=\left(1-\sin ^{2} \phi\right) /\left(1+\sin ^{2} \phi\right)
$$

2. The coefficient of earth pressure at rest, $\mathrm{K}_{\mathrm{o} \text {. present equ. }}$ decreases with increase of the angle of internal friction, $\phi$ and the relationship can be represented as straight line as

$\mathrm{K}_{\mathrm{o} \text { present equ. }}=1.16414-0.01884 \phi$.

3. The Deviation from present equ.and Jaky equ about $20 \%$ at $\phi=25: 30$, about $19 \%$ at $\phi=31: 33$, about $18 \%$ at $\phi=34: 36$ and about $16.5 \%$ at $\phi=37: 40 \%$. The deviation decreases with increase of the angle of internal friction, $\phi$

4. The relationship between $\mathrm{K}_{\mathrm{o} \text {. present }}$ and $\mathrm{K}_{\mathrm{o}}$. Jaky for sandy soils is: $\mathrm{K}_{\text {opresent }}=1.2795 \mathrm{~K}_{\text {oJaky }}-0.04044$

For $\phi=25: 40^{\circ}$ it is noticed that $\mathrm{K}_{\mathrm{o}}$ present increases with the increase of $\mathrm{K}_{\mathrm{o}}$ Jaky and the relationship between them is a straight line.

5. The relationship between the angle of internal friction, $\phi$ and the relation of $\mathrm{K}_{\mathrm{o} \text { present }} / \mathrm{K}_{\mathrm{o} \text { Jaky }}$ for sandy soils can be written as:

$\mathrm{K}_{\mathrm{o} \text { present }} / \mathrm{K}_{\mathrm{o} \text { Jaky }}=1.3011-0.0033 \phi$. 


\section{REFERENCES}

1. Donath, A. D. (1891)."Untersuchungen veber den Erddruck auf Stuetzwaende. "zeitschrift fuer Bauwesen,Berlin,Germany.Cited from Hanna, A. ,and Ghaly, A., "Effect of $K_{0}$ and overconsolidation on uplift capacity "journal of Geotchnical Engineering ASCE, Vol. 118, No. 9, September, (1992)

2. Terzaghi, K. (1920) . "Old earth pressure theories and new test results." Engrg. News-Rec., 85(14), PP. 632 - 637. Cited from Hanna, A. ,and Ghaly, A., "Effect of $K_{0}$ and overconsolidation on uplift capacity "journal of Geotchnical Engineering ASCE, Vol. 118, No. 9, September, (1992) .

3. Jaky, K. (1943) : Natural Earth Pressure ( in Hungarian) . Technica,No. 9. Cited from "Robert Szepeshazi"On the $K_{0}$ factor - Periodica polytechnica ser. Civil. Eng. Vol. 38, No. 1, PP. 127-195 (1994).

4. Lo, K. Y. - LEE, C. F. (1973) : Analysis of Progressive Failure in clay slopes . proc. $8^{\text {th }}$ Int. Conf. on soil Mech. and Found. Eng., Vol. 1, Moszkva. Cited from "Robert Szepeshazi"On the $K_{0}$ factor - Periodica polytechnica ser. Civil. Eng. Vol. 38, No. 1, PP. 127-195 (1994).

5. Fourie, A. B. - Potts, D. M. (1989):Comparison of Finite Element and Limiting Equilibrium Analyses for an Embedded Cantilever Retaining Wall . Geotechnique, Vol. 39, No. 2. Cited from "Robert Szepeshazi"On the $K_{0}$ factor - Periodica polytechnica ser. Civil. Eng. Vol. 38, No. 1, PP. 127-195 (1994).

6. Kjellman , W. (1936) "Report on an apparatus for the determination of the coefficient of lateral earth pressure at-rest" proc., First Int.Conf. on soil Mechanics and Found. Engrg., Harvah printing Office, Cambridge , Mass., 2, 16 - 20 Cited from Hanna, A. ,and Ghaly, A., "Effect of $K_{0}$ and overconsolidation on uplift capacity "journal of Geotchnical Engineering ASCE, Vol. 118, No. 9, September, (1992).

7. Jaky, J. (1944). "The coefficient of earth pressure at rest ." J. Soc. Hungarian Arch. Engrs., 78(22), 355-358 ( in hungarian ) Cited from Hanna, A. ,and Ghaly, A., "Effect of $K_{\circ}$ and overconsolidation on uplift capacity "journal of Geotchnical Engineering ASCE, Vol. 118, No. 9, September, (1992) .

8. Jaky, J. (1948)."Pressure in Silos."Proc., $2^{\text {nd }}$ Int.Conf. on soil Mech.and Found. Engrg., A. A. Balkema, Rotterdam, the Netherlands, Vol. 1, 103-107. Cited from Hanna, A. , and Ghaly, A., "Effect of $K_{0}$ and overconsolidation on uplift capacity "journal of Geotchnical Engineering ASCE, Vol. 118, No. 9, September, (1992) .

9. Bishop, A. W. (1958). "Test requirements for measuring $K_{\odot}$ " proc., Brussels conf. on earth pressure problems, Belgium Group, Int. Soc. of Soil Mech. and Found. Engrg., Brussls, Belgium, 2 - 14 . Cited from Hanna, A. ,and Ghaly, A., "Effect of $K_{\odot}$ and overconsolidation on uplift capacity "journal of Geotchnical Engineering ASCE, Vol. 118, No. 9, September, (1992) .

10. Hendron,A. (1963). "The behavior of sand in one- dimensional compression." Ph.D.Thesis, University of Illinois, Urbana, Ill. Cited from Hanna, A. ,and 
Ghaly, A., "Effect of $K_{0}$ and overconsolidation on uplift capacity "journal of Geotchnical Engineering ASCE, Vol. 118, No. 9, Sept. , (1992) .

11. Saglamer, A. (1975). "Soil parameters Affecting coefficient of earth pressure at-rest of cohesionless soils." Proc. Istanbul Conf. on Soil Mech. and Found. Engrg., Turkiya Bilimsel ve Teknik Arasfirma Kurumu, Ankara, Torkey, vol. 1, PP. $9-16$. Cited from Hanna, A. ,and Ghaly, A., "Effect of $K_{\odot}$ and overconsolidation on uplift capacity "journal of Geotchnical Engineering ASCE, Vol. 118, No. 9, Sept., (1992) .

12. Wenkow. W., "An apparatus for the evaluation of the coefficient of earth pressure at - rest, " Design Parameters in Geotechnical Engineering, BGS, Vol. 2, pp. 171 - 174 , (1979) . Cited from Mostafa , A. , Abdou" investigation of the distribution of earth pressure on caissons and shells "(1995).

13. Tshebotarioff, G. P. "Soil Mechanics, Foundations and Earth Structures, " MCGRAW - HILL BOOK, Publishing company, Inc. , (1951)

14. Robert Szepeshazi "On the $K_{0}$ Factor " Periodica Polytechnica Ser. Civil. Eng. Vol. 38, No. 1, PP. 127-195 (1994).

15. Brooker, E. Q., and Ireland , H. O.,"Earth pressre at-rest related to stress history,"Canadian Geotechnical Journal, vol. 2, No. 1, 1965, PP. 1-15 Cited from Salah Abdelhamid, A. M.ASCE and Raymond J. Krizek, M. ASCE" At rest Lateral Earth Pressure of consolidating Clay "Journal of the Geotechnical Engineering Division vol. 102 NO.GT7 PP. 732, JULY (1976).

16. Matsuoka, H. - Sakakibara, k. (1987) : A constitutive Odel for sands and Clays Evauating Principal Stress Rotation . soils and Foundation, Vol. 27, No.

4. Cited from Robert Szepeshazi "On the $K_{0}$ Factor" Periodica polytechnica Ser. Civil. Eng. Vol. 38, No. 1, PP. 127-195 (1994).

17. Simpson, B . "Retaining structures: displacement and design" Geotechnique 42, No. 4, 541-576 (1992).

18. Rowe,P.," $c_{\theta}=0$ Hypothesis for Normally Loaded Clays at Equilibrium ,"proceedings of the Fourth International Conference of soil Mechanics and foundation Engineering, London, England, vol. 1, 1957, PP. 189-192 Cited from Salah Abdelhamid, A. M.ASCE and Raymond J. Krizek, M. ASCE " At -rest Lateral Earth Pressure of consolidating Clay "Journal of the Geotechnical Engineering Division vol. 102 NO.GT7 PP. 732-733, JULY (1976).

19. Andrawes, K. Z., and El- sohby, M. A. (1973). "Factors affecting coefficient of earth pressure $K_{0}$ " (proc.paper 9863). Cited from Umesh Dayal and J. H. Allen, M. Discussion Affecting Cofficient of Earth Pressure $K_{\circ}$ May (1974).

20. Andrawes, K. Z., and El- sohby, M. A. (1973). "Factors affecting coefficient of earth pressure $K_{\odot}$ "J . Soil Mech. and Found. Div., ASCE, 99(7), 527-539 . Cited from Hanna, A. , and Ghaly, A., "Effect of $K_{0}$ and overconsolidation on uplift capacity "journal of Geotchnical Engineering ASCE, Vol. 118, No. 9, September, (1992). 
21. Hanna, A., and Ghaly, A., "Effects of $K_{0}$ and Overconsolidation on Uplift Capacity "Journal of geotechnical Engineering Vol. 118 No. 9 Sep. (1992).

22. Moroto, N. and Muramatsu. M. (1987) , " $K_{\mathrm{o}}$ value and degree of anisotropy of overconsolidated clay ", proceeding $9^{\text {th }}$ southeast Asian geotechnical conference, sec. 5 pp.25-32 Cited from Richard church ECI-284 " At - rest earth pressure relationships " theoretical geomechincs (2003).

23. Craig, R. F. , "Soil mechanics ," published by Van Nostrano Reinhold Company Ltd., (1974) Cited from Mostafa, A., Abdou" investigation of the distribution of earth pressure on caissons and shells .(1995) .

\section{دراسة الضغوط الجانبية للتربة الرملية عند السكون}

يعتبر ضغط التربة من اهم الموضوعات فى مجال الهندسة الددنية لان كثير من المنشات الهندسية تتعرض

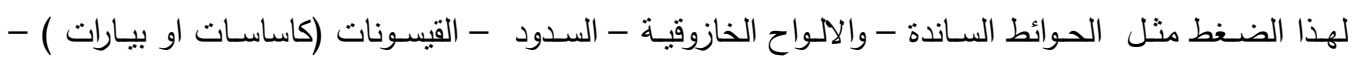

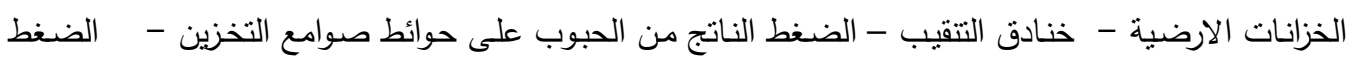
الجانبى للصخر على الانفاق - والمنشات الارضية وخلافة.

كما يعتبر معامل الضغط الجانبي للتربة عند السكون متغير هام جدا فى تصميم وتحليل العديد من المشاكل الهندسية الخا صة بالمنشات الارضية ويتمثل فى حساب القوى الجانبية الناتجة من التربة على المنشات النية الساندة

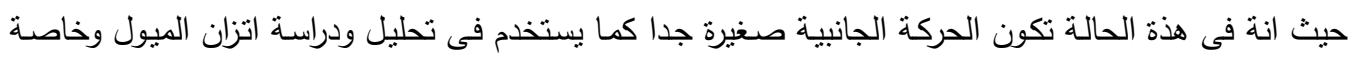

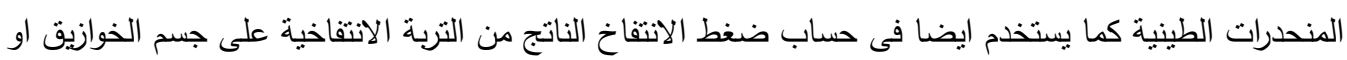

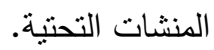

ولهذه الاهمية قام كثير من الباحثين والعلماء مثل ( جاكى - بروكرو ايرلند - ماتسوكا - بولنن - فيرسبيسكى -

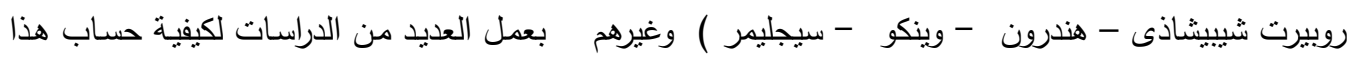

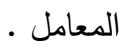

وفى هذا البحث اجريت دراسة نظرية باستخدام العلاقة بين الضغط الجانبى (ضغط التربة الفعال - ضغط التربة الدقاوم ) والانفعال الجانبي ومن خلالها تم التوصل الى معادلة لحساب معامل الضغط الجانبى للتربة الرملية

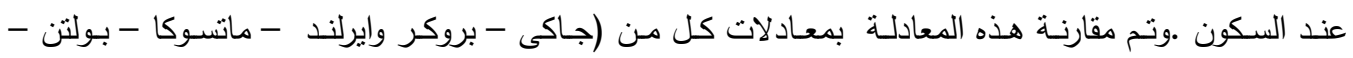

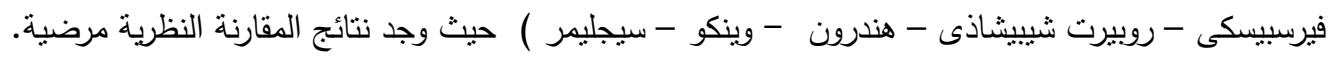
كما يحتوى البحث على بعض النتائج الهامة الاخرى. 